\title{
Student's Knowledge Profil of Local Character Values in Learning Social Science at Elementary School
}

\author{
Rokayah \\ Universitas Pendidikan Indonesia \\ Bandung, Indonesia \\ yoyok1972@yahoo.co.id
}

\begin{abstract}
This research designed: (1) to identify the material of teaching; (2) to explore the Social Science teachers of elementary school in understanding on innovative learning models in Elementary School of Tulus Kartika; (3) to formulate the draft of Local Wisdom-Based Social Science learning model in Elementary School as the attempt of improving Social Learning Quality and confirming the character of students. Techniques of collecting data used were observation, interview, document analysis, questionnaire and FGD (Focus Group Discussion). The data analysis method employed was an interactive model of qualitative analysis. The result of research showed that: (1) the objective of Social Science learning was to develop social knowledge, attitude, and skill of students; the material had been consistent with Standard Content; the lecturing method was varied; (2) the Social Science teachers of : (1) to identify the material of teaching; (2) to explore the Social Science teachers of elementary school understanding of innovative learning models in Elementary School of Tulus Kartika; (3) to formulate the draft of Local Wisdom-Based Social Science learning model in models in Elementary School as the attempt of improving Social Learning Quality and confirming the character of students. Elementary School had understood the innovative learning model, and (4) a Local Wisdom-Based Social Science learning model had been developed with local character values as a learning source.
\end{abstract}

Keywords-Social Science learning, Social Science teacher, Elementary School, and Local character Values

\section{INTRODUCTION}

Instruction is a conscious and strategic attempt of realizing a learning process to encourage the students to develop their ability in order to have religious spiritual power, self-control, personality, intellectuality, noble character, and skill in their society, their nation and state need. Law about National Education accoding to [1] explains that national education serves to develop capacity and to provide nation character and respected civilization in the attempt of intellectualizing the nation life, targeting to develop the students' potential to be human beings who have faith, piety to Almighty God, noble character, are healthy, knowledgeable, competent, creative, independent, and become democratic and responsible citizens. Such the formulation of education objectives is ideal and complete. It is formulated deliberately to provide spiritual context and spirit as well as to give inspiration to every related mortality component to try achieving such the ethics. Though, in the employment of organization, education as the nationbuilding process is still upsetting. The development of common life is still characterized by the gap of moral, character, social economic and politic problems, and nation's self-esteem. It is these difficulties that surface widely today in Indonesia. It directs that our education has not been able to develop Indonesian human and society as estimated [2]. This is, of sequence, not reliable with the denotation and the intention of Social Science learning. It is because Social Science education and learning, in addition, to be academic in nature, also implants value, develops social problem-solving skill, reconstructs event, wisdom and moral lesson problem, independence, responsibility, discipline, and entrepreneur spirit [2]. This statement offers the Student's Knowledge Profil Of Local Character Values in Learning Social Science at Elementary School.

\section{METHODS}

The type of research was development research and was conducted gradually for two grade, namely the fifth and the sixth grade. Thus, the method classification during this two grade is an integral unit in solving the main problem studied. In the grade fifth and grade sixth, this research was conducted: (1) to identify the material of teaching; (2) to explore the Social Science teachers of elementary school understanding of innovative learning models in Elementary School of Tulus Kartika; (3) to formulate the draft of Local Wisdom-Based Social Science learning model in models in Elementary School as the attempt of improving Social Learning Quality and confirming the character of students. Explorative research is intended to reveal in depth the Social Science learning model undertaken so far in models in Elementary School of Tulus Kartika. FGD is intended to get input from various related parties as the main material for developing the draft of Local Wisdom-Based Social Science learning model. 


\section{RESULTS AND DISCUSSIONS}

Connected to objective, material, method, and evaluation of Social Science Learning accepted in Elementary School Tulus Kartika today, the following elaboration can be given.

\section{A. Objective of Social Science Learning}

Related to the objectives of Social Science learning, the result of observation record, the interview with Social Science teachers of Elementary School Tulus Kartika Bandung City, and the collection study, it can be elaborated as follows. It is aligned Ref [3] and Ref [4] state of Social Sciences is the field of teaching provided in schools with the aim to develop the knowledge, attitudes, and social skills. Ref [5] mentions the purpose of social studies is to develop the knowledge, skills, attitudes, and values.

\section{B. Social Science Learning Material}

The scope of Social science learning material for Elementary School Tulus Kartika includes the following aspects: (1) human, place, and environment, (2) time, sustainability, and change, (3) social and cultural system, and (4) economic behavior and welfare. Particularly for the fifth and sixth grade, the scope of the material consists of (1) understanding the human's attempt of recognizing environment development, (2) understanding the community's economic activity (Depdiknas National Education Department).

Learning program is part of the curriculum which is also called the learning plan [6], which says that the curriculum is learning plan that includes the learning process and learning objectives in order to improve the quality of education [7]. The learning process also shows the results of achievement of competencies. Curriculum as learning plan Rer [1] which is a set of plans and arrangements regarding the content and learning materials as well as the means used to guide the implementation of teaching and learning activities that allow interaction between learners and between learners by teachers [8].

Social Science learning program is the integration of the social education of humanity [3] \& [8]. Social Science education is given to prepare citizens who are able to make decisions reflective and actively participate in civic life in the community, nation and world, including the interaction between individuals [3] \& [9]. Farther from the interaction of social occur through social information processing that involves giving attention to behaviors that show others and interpretation or meaning to these behaviors [10].

School should be a formal institution that is able to instill morals early. As an institution that plays a role change behavior through moral learning should be a core competency in teaching and learning activities to become a good citizen. [11] $\&$ [12]. While the dimensions of the action (action) in the form of skill competencies interact with the environment integrated into the development consistent with the moral and psychological development of children [13]; [14]. Social sciences have formal programs that must be taken by students to acquire the competencies outlined. Ref [14] explains that the IPS is part of the school curriculum, whose main responsibility is to assist students in developing the fabric of knowledge, skills, attitudes, values and interconnected in a comprehensive manner [15]; [16] \& [3]

\section{Profile Of Understanding Local Cultural Knowledge Of The Character Values}

The ability to understand local cultural knowledge of the character values of students in the IPS material fifth and sixth grade can be shown by the following chart.

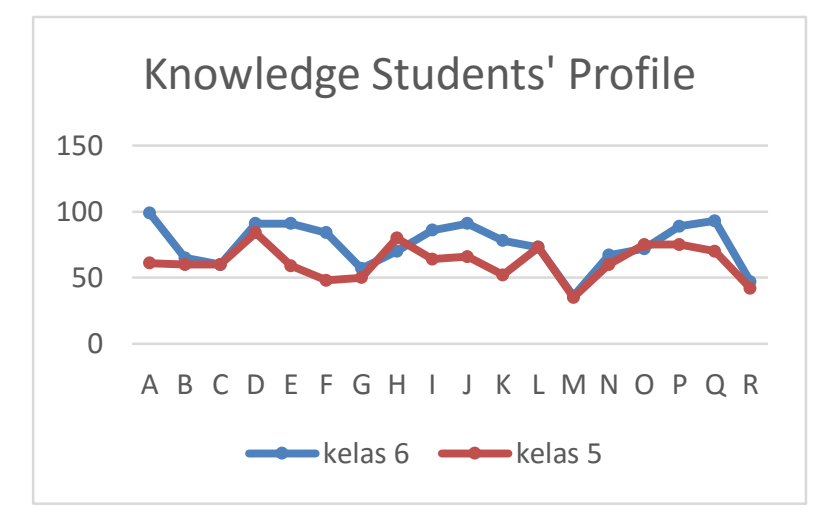

Fig. 1. Profil Knowledge Students'

The above graph shows that the understanding of knowledge profiles sixth grade higher than the grade five. Grade 6 students understanding better than grade 5 because of the level of their understanding of teaching materials about the value of local character have been better. In addition, they experience better interact with the environment due to factors that influenced the development of learners ages. Based on these data and the results of field and Focus group discussions can teachers develop teaching materials with the inclusion of social science philosophy of the character values of local culture more broadly and deeply. Selection of the appropriate method based on these data is a method that contains elements of cooperation, active interaction, modeling and communication as a means of interacting orally active.

\section{CONCLUSION}

Bearing in mind the result of research and discussion, the following conclusions can be drained. (1) The objective of Social Science learning is to develop knowledge, attitude, skill, and value; Social Science learning consistent with Content Standard in the Curriculum of Social Science for Elementary School; varying lecturing method and evaluation leading to knowledge, attitude and skill aspects. (2) The teachers of Elementary School in Tulus Kartika Bandung have implicit and practiced innovative learning model. (3) The development of Local Wisdom-Based Social Science Learning model. From conversation and conclusion above, the following endorsements can be given. (1) Social Science teacher as a designer should be able to set the material well. (2) The use of innovative learning model should be enhanced because of the application of learning model, in addition to minimizing the time, also makes the learning more interesting and delighted. (3) Social Science learning is replete with value; therefore the teachers of Social Science do not only "transfer of knowledge" but also "transfer of values". The character values to be 
advanced finished Social Science in general and local wisdom in particular included: discipline, responsibility, environment caring, social caring, religiosity, nationality spirit, loving to the homeland, reading interest, sacrificing, creativity, honesty, independence and hard work.

\section{REFERENCES}

[1] Anonim. (2007). Undang-Undang No.20 Tahun 2003 Tentang Sistem Pendidikan Nasional. Yogyakarta: Pustaka Pelajar.

[2] Nurhadi. (2006). Kurikulum 2004, Pertanyaan dan Jawaban. Jakarta : PT Gramedia Widiasarana Indonesia

[3] Sapriya.(2009). Pendidikan IPS, Konsep dan Pembelajaran.Bandung: Rosda karya

[4] Cholisin dan Hisyam, Djihad (ed). (2006). Reorientasi dan pengembangan ilmu pengetahuan sosial di era Indoensia baru. Yogakarya : HISPISI dan FISE

[5] Fraenkel, Jack R. (1980). Helpind Student Think and Value Strategies for Teaching the Social Studies.New Jersey: Prentice Hall, Ins

[6] Jack, F. (1997). Helping Students Think and Value Strategies for Teaching the Social Studies.Englewoodcliffs; New Jersey, Prentices Hall, Inc.
[7] Banks, James A. (2010). Multicultural Education. USA: RRD Crawfordsville.

[8] Van Cleaf, David W (1991. Action In Elementary Sosial Studies. Massachusetts: A Division of Simon\& Schuter Inc.

[9] Sanjaya, Wina. (2009). Kurikulum dan Pembelajaran. Jakarta: Kencana Prenada Media Group.

[10] Ormrod, Jeanne Ellis. (2008). Psikologi Pendidikan. Jakarta: Erlangga.

[11] Benninga, Jacques S. Moral, Character, and Civic Education in the Elementary School.Teacher College, Columbia University: New York and London.

[12] Wahab, abdul azis \& Sapriya.(2012). Teori \& Landasan Pendidikn Kewarganegaraan. Bandung: Alfabetha

[13] Miller, Richad, Fielding. (1980). Models Of Moral Education. New York: Longmann.

[14] Maryani, E. Syamsudin, H. (2009). Pengembangan Program Pembelajaran IPS Untuk Meningkatkan Kompetensi Keterampilan Sosial. Jurnal Penelitian. Vol 9 No. 1

[15] Sukmadinata, Nana Syaodih. (2011). Pengembangan Kurikulum. Teori dan Praktek.Bandung:

[16] Ali, Mohammad. (2007). Teori dan Praktek Pembelajaran Pendidikan Dasar. Bandung. 